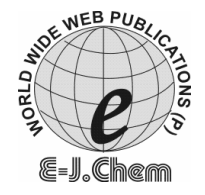

http://www.e-journals.net
ISSN: 0973-4945; CODEN ECJHAO

E-Journal of Chemistry

2009, 6(1), 161-168

\title{
Adsorption of Copper and Iron Using Low Cost Material as Adsorbent
}

\author{
TARIQ S. NAJIM*, NAZIK J. ELAIS and ALYA A. DAWOOD \\ Dohuk University, College of Education, \\ Department of Chemistry, Dohuk, Iraq. \\ tariq_pru@yahoo.com
}

Received 14 May 2008; Accepted 10 July 2008

\begin{abstract}
In this study, pine fruit was used as solid adsorbent for removal of ferrous and copper ions from aqueous solutions through batch equilibrium technique. The influence of contact time, $\mathrm{pH}$ of the solution and initial concentration of metal ions on adsorbed amount of metal ions were investigated. 90 minutes of adsorption time was found sufficient to reach equilibrium for ferrous ion and 120 minutes for copper ion. Adsorption of metal ions were $\mathrm{pH}$ dependent and the results indicate the optimum $\mathrm{pH}$ for the removal of $\mathrm{Fe}^{+2}$ was found to be 5.0 and that of $\mathrm{Cu}^{+2}$ was 7.0, the highest adsorption capacity was found to be 4.8 and $14.1 \mathrm{mg}$ of metal ion per gram of adsorbent at initial concentration of $22.22 \mathrm{mg} / \mathrm{L}$ and $57.6 \mathrm{mg} / \mathrm{L}$ of ferrous and copper ions respectively and would be higher with higher initial concentration. Ferrous ion was removed by $96.3-97.3 \%$ and copper ion by $94.1-96 \%$ along the whole range of initial concentrations. Isotherm studies showed that the data were best fitted to the Freundlich isotherm model. The kinetic data corresponded well with the pseudo-second order equation, suggesting that the adsorption process is presumably a chemisorption.
\end{abstract}

Keywords: Adsorption, Pine fruit, Freundlich isotherm, Metal ions Removal.

\section{Introduction}

The presence of heavy metals in the environment is one of the major concerns because of their toxicity and threat to human life and environment. Metal ions are non-biodegradable in the nature and therefore, their intakes at certain level are toxic ${ }^{1}$. For example, copper is both vital and toxic for many biological systems ${ }^{2}$. 
The increasing stringent environmental regulation and enforcement of discharge limits require effective decontamination and purification method. From the analytical point of view, it is known that solid phase extraction (adsorption) is an attractive technique based on the use of the sorbent that retains analytes. The adsorption process, proved its advantage over the other processes because of its cost effectiveness and the high-quality of the treated effluent it produces. Activated carbon is widely used as an adsorbent due to its high adsorption capacity ${ }^{3-5}$. Different cheap adsorbents are used or under investigations of these peat, marine algae, clays, maize cob, bagasse, palm fruit bunch, lalang leaf, saraca indica leaf and nile rose plant, which were used to remove dyes and metal ions from waste water ${ }^{6-13}$. Beside that many chelating polymers have been used for this purpose ${ }^{14-18}$. The cell wall of most agricultural waste contains natural polymers like cellulose, hemicellulose, pectins and lignin which are the most important sorption sites ${ }^{19}$. The present study undertaken to evaluate the efficiency of pine fruit powder for removal of ferrous and copper ions in aqueous solution, in addition to estimate the optimum removal conditions and the suitable adsorption isotherms with their related constants.

\section{Experimental}

Dried pine fruit were milled and grounded until it passed through 80 mesh sieve. The powdered pine fruit was washed repeatedly with distilled water to remove dust and soluble impurities. All chemicals used of high purity, commercially available Analar grades. Stock solution of $1000 \mathrm{mg} / \mathrm{L}$ of ferrous sulfate $\left(\mathrm{FeSO}_{4} .7 \mathrm{H}_{2} \mathrm{O}\right)$, and copper sulphate $\left(\mathrm{CuSO}_{4} .5 \mathrm{H}_{2} \mathrm{O}\right)$ was prepared using deionized water. From that, 4.87, 9.52, $13.95,18.18,22.22 \mathrm{mg} / \mathrm{L}$ of ferrous ion solutions and 11.9, 22.7, 41.6, $57.6 \mathrm{mg} / \mathrm{L}$ of copper ion solutions were prepared in buffer solution. The adsorption was carried out in a batch process at $\left(32 \pm 1^{\circ} \mathrm{C}\right)$ in the presence of $100 \mathrm{mg}$ of adsorbent (pine fruit powder) under constant shaking at $350 \mathrm{rev} / \mathrm{min}$ with orbital shaker IKA KS 130. The effect of the $\mathrm{pH}$ of the suspending medium on metal removal was studied by performing equilibrium sorption tests at different $\mathrm{pH}$ values. The effect of contact time and initial concentration of metal ions were also examined by choosing different time intervals of shaking the pine fruit powder with metal ions solutions.

The sealed conical flasks were shaken at constant temperature $\left(32 \pm 1^{\circ} \mathrm{C}\right)$ for 90 and 120 minutes for ferrous and copper ions respectively, where equilibrium was attained. Resultant metal ion solution concentration $\mathrm{C}_{\mathrm{e}}$, were determined by the atomic absorption spectrophotometer (AAnalyst200 Perkin Elmer). The amount of metal sorbed at equilibrium, $\mathrm{q}_{\mathrm{e}} \mathrm{mg} / \mathrm{g}$, was determined using the following equation:

$$
q_{e}=\frac{V\left(C_{i}-C_{e}\right)}{M}
$$

Where: $\mathrm{V}=$ Volume of equilibrated solution.

$\mathrm{M}=$ ass of adsorbent.

$\mathrm{C}_{\mathrm{i}}=$ initial concentration of metal ion.

$\mathrm{C}_{\mathrm{e}}=$ equilibrium concentration of metal ion.

Percent removal (R\%) was also evaluated from the following equation:

$$
R \%=\frac{C_{i}-C_{e}}{C_{i}} \times 100
$$




\section{Results and Discussion}

\section{Effect of $p H$}

The experiments were carried out at different $\mathrm{pH}$ shows that there was a change in the quantity of adsorbed ferrous and copper ions on the solid phase of pine fruit powder over the entire $\mathrm{pH}$ range of 3.6 to 8.0, although the change for copper was simple compared with ferrous, as shown in Figure 1 and Table 1. This indicates the strong force of interaction between the ferrous ions and the pine powder that, $\mathrm{H}^{+}$ion could influence the adsorption capacity. Here the interaction is more at $\mathrm{pH} 5$ (Figure 1 and Table 1) due to the competence of acidic $\mathrm{H}^{+}$ion with metal cation for the sorption sites. The maximum interaction of copper ions with pine powder at $\mathrm{pH} 7$ (Table 1 and Figure 1). The adsorption of metal ions on the pine fruit powder does involve ion exchange mechanism ${ }^{20}$.

Table 1. Equilibrium parameters for the adsorption of metal ions onto pine fruit powder at different $\mathrm{pH}$.

Temperature $32 \pm 1^{\circ} \mathrm{C} ; \mathrm{C}_{\mathrm{i}}=20 \mathrm{mg} / \mathrm{L}$ for $\mathrm{Fe}^{+2} ; \mathrm{C}_{\mathrm{i}}=11.9 \mathrm{mg} / \mathrm{L}$ for $\mathrm{Cu}^{+2}$.

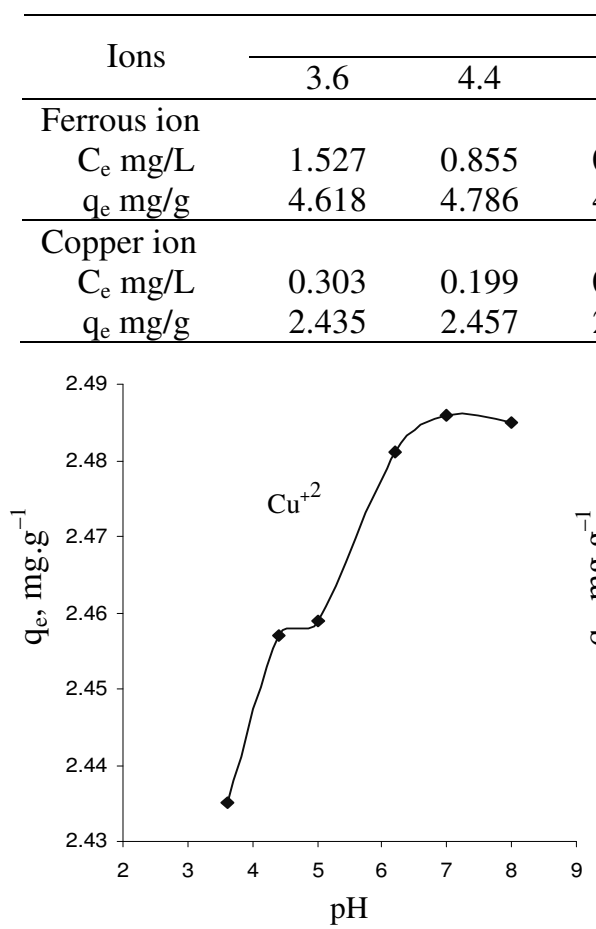

\begin{tabular}{cccc}
\multicolumn{2}{c}{$\mathrm{pH}$} & & \\
5.0 & 6.2 & 7.0 & 8.0 \\
0.175 & 0.815 & 1.188 & 1.373 \\
4.926 & 4.796 & 4.703 & 4.656 \\
0.187 & 0.083 & 0.059 & 0.063 \\
2.459 & 2.481 & 2.486 & 2.485 \\
\hline
\end{tabular}

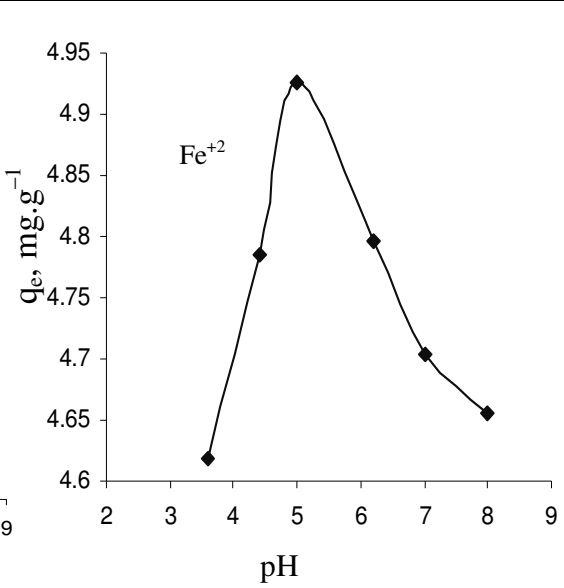

Figure 1. Effect of $\mathrm{pH}$ on removal of ferrous and copper ions onto pine fruit powder.

\section{Effect of contact time}

The effects of contact time on the amount of metal ions on adsorbent surface are shown in Table 2 and Figure 2. Equilibrium have established at 90 minutes for ferrous ions and 120 minutes for copper ions. Figure 2 reveals that the curves are smooth and continuous, leading to saturation, suggesting the possible monolayer coverage of the metal ions on pine powder surface $^{5}$. Once again there is not a big change of amount of metal ion adsorbed with time, which give an indication of ion exchange mechanism. 
Table 2. Equilibrium parameters for the adsorption of metal ions onto pine fruit powder at different time interval.

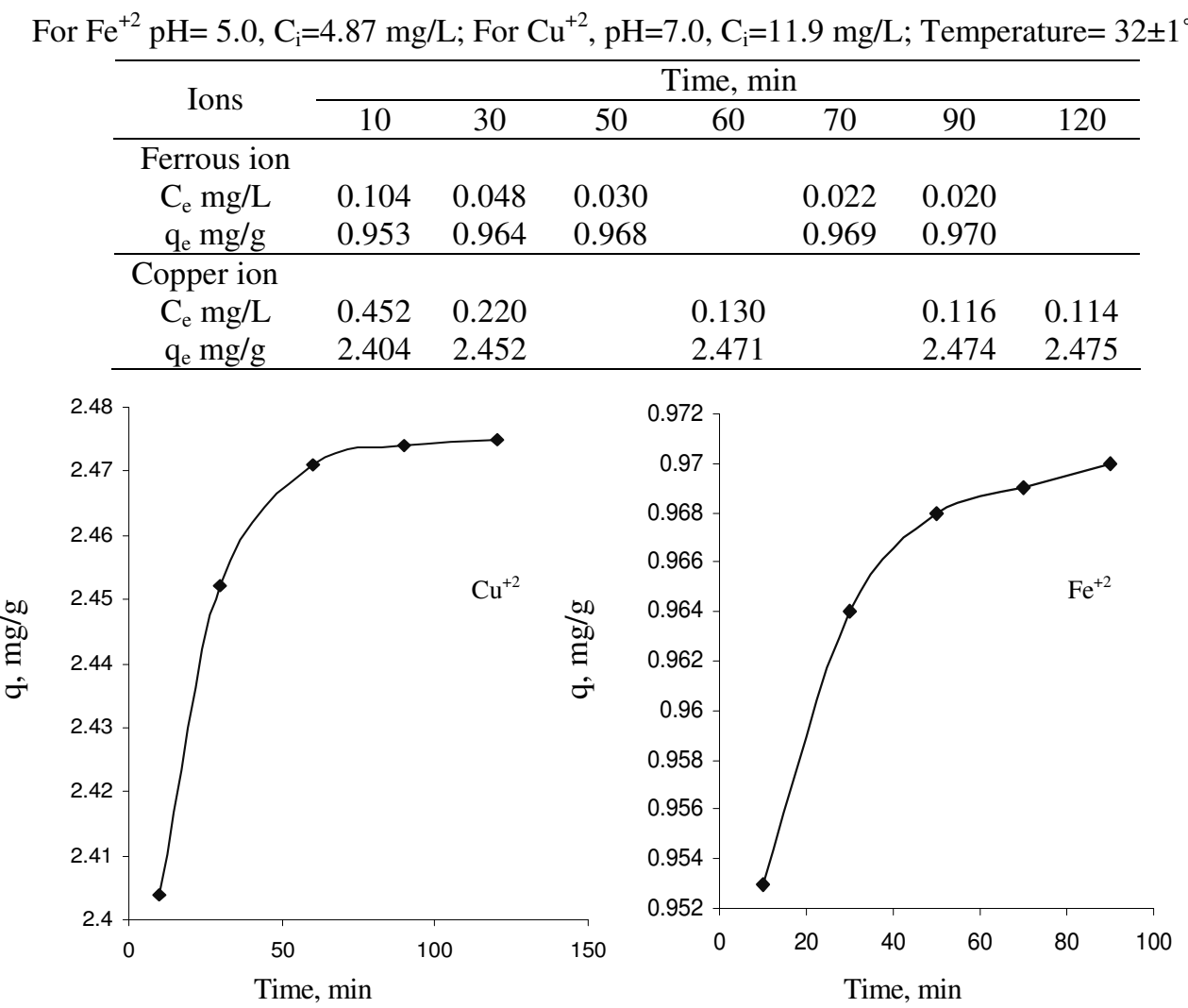

Figure 2. Effect of contact time on copper and ferrous ions adsorption onto pine fruit powder.

The applicability of the pseudo-first-order and pseudo-second-order kinetic models was tested for the adsorption of metal ions onto pine fruit powder. The best fit model was selected based on both linear regression correlation coefficient and the calculated $\mathrm{q}_{\mathrm{e}}$ values. The Langergren equation, pseudo-first-order equation, describes the kinetics of adsorption process as follows ${ }^{21}$ :

$$
\log \left(q_{e}-q_{t}\right)=\log q_{e}-\left(\frac{K_{1}}{2.303}\right) t
$$

Where $\mathrm{q}_{\mathrm{t}}$ and $\mathrm{q}_{\mathrm{e}}$ are the amount of metal ion adsorbed $\left(\mathrm{mg} \mathrm{g}^{-1}\right)$ at any time and equilibrium time respectively, $\mathrm{k}_{1}$ is the first order rate constant $\left(\mathrm{min}^{-1}\right)$. According to the adsorption equation, the experimental result of Figure 2 can be converted into the plots of $\log \left(\mathrm{q}_{\mathrm{e}}-\mathrm{q}_{\mathrm{t}}\right)$ versus $\mathrm{t}$, Figure 3 . Values of $k_{1}$ were calculated from the plot of $\log \left(q_{e}-q_{t}\right)$ versus $t$ for metal ions. Although, the correlation coefficient values are higher than 0.99 , the experimental $\mathrm{q}_{\mathrm{e}}$ values do not agree with the calculated one, obtained from the linear plot, Table 3 . This shows that the adsorption of copper and ferrous ions onto pine fruit powder is not a first order reaction.

The second-order kinetic model ${ }^{22}$ is expressed as:

$$
\frac{t}{q_{t}}=\frac{1}{k_{2} q_{e}^{2}}+\frac{t}{q_{e}}
$$


Where $\mathrm{k}_{2}\left(\mathrm{~g} \mathrm{~min}^{-1} \mathrm{mg}^{-1}\right)$ is the rate constant of second order adsorption. If second order kinetics is applicable, the plot of $\mathrm{tq}_{\mathrm{t}}^{-1}$ versus $\mathrm{t}$ should show a linear relationship. The equilibrium adsorption capacity, $\mathrm{q}_{\mathrm{e}}$ can be calculated from equation 4 . Also, it is more likely to predict the behavior over the whole range of adsorption. $\mathrm{k}_{2}$ and $\mathrm{q}_{\mathrm{e}}$ were calculated from the intercept and slope of the plot of $\mathrm{tq}_{\mathrm{t}}^{-1} v s$ t. the linear plots at Figure 4 show good agreement between experimental and calculated values, Table 3, The correlation coefficient for the second order kinetic model was 1 for both metal ions indicating the applicability of this kinetic equation and the second order nature of the adsorption process of ferrous and copper ions onto pine powder. This suggest that the adsorption of metal ions onto pine powder is presumably a chemisorption process involving exchange and sharing of electrons mainly between metal cations and functional groups of the pine fruit powder ${ }^{23}$

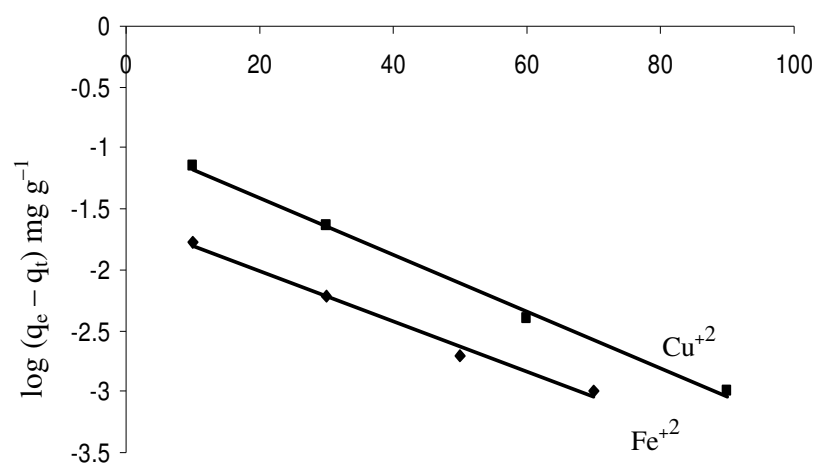

Time, $\min$

Figure 3. Plot of time versus $\log \left(\mathrm{q}_{\mathrm{e}}-\mathrm{q}_{\mathrm{t}}\right)$ for adsorption of ferrous and copper ions on pine fruit powder.
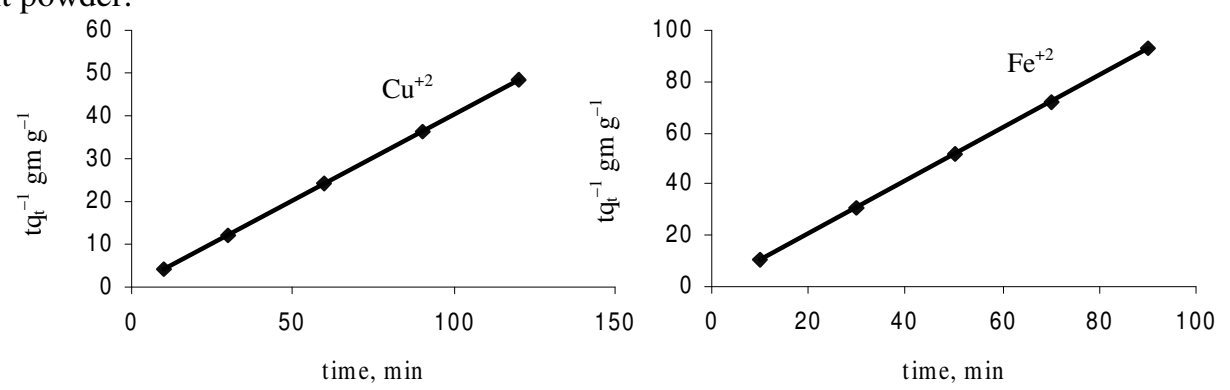

Figure 4. Plot of time versus $\mathrm{tq}_{\mathrm{t}}^{-1}$ for adsorption of ferrous and copper ions onto pine fruit powder.

Table 3. Comparison of the first and second order adsorption rate constants and calculated and experimental $\mathrm{q}_{\mathrm{e}}$ values for ferrous and copper ions.

\begin{tabular}{|c|c|c|c|c|c|}
\hline & $\mathrm{q}_{\mathrm{e}}(\exp ) \mathrm{mg} \mathrm{g}^{-1}$ & $\mathrm{k}_{1} \min ^{-1}$ & $\mathrm{k}_{2} \mathrm{~g} \mathrm{mg}^{-1} \min ^{-1}$ & $\mathrm{q}_{\mathrm{e}}$ (cal.) $\mathrm{mg} \mathrm{g}^{-1}$ & $\mathrm{R}^{2}$ \\
\hline \multicolumn{6}{|c|}{ First order kinetic model } \\
\hline Ferrous & 0.970 & 0.046 & & 0.026 & 0.991 \\
\hline Copper & 2.475 & 0.054 & & 0.115 & 0.997 \\
\hline \multicolumn{6}{|c|}{ Second order kinetic model } \\
\hline Ferrous & 0.970 & & 4.55 & 0.972 & 1 \\
\hline Copper & 2.475 & & 1.24 & 2.482 & 1 \\
\hline
\end{tabular}




\section{Effect of initial concentration}

The experimental results of adsorption of metal ions on pine fruit powder at various initial concentrations $(4.87,9.52,13.95,18.18,22.22 \mathrm{mg} / \mathrm{L})$ for ferrous ion and (11.9, 22.7, 41.6, $57.6 \mathrm{mg} / \mathrm{L}$ ) for copper ion. The equilibrium data are given in Table 4 . It reveals that, the actual amount of metal ions adsorbed per unit mass of pine fruit powder increased with increase in metal ions concentration. It means that the adsorption is highly dependent on initial concentration of metal ion. It is because of at lower concentration, the ratio of initial number of metal ions to the available surface area is low subsequently the fractional adsorption become independent of initial concentration. However, at high concentration the available sites of adsorption becomes fewer and hence the adsorption of metal ions is dependent upon initial concentration. The relation between the amount of metal ion adsorbed on the adsorbent surface $(\mathrm{mg} / \mathrm{g})$ and the initial concentration of ferrous and copper ions are shown in Figure 5.

Table 4. Equilibrium parameters for the adsorption of metal ions onto pine fruit powder at different initial concentrations.

\begin{tabular}{|c|c|c|c|c|c|c|}
\hline \multicolumn{2}{|c|}{$\mathrm{C}_{\mathrm{i}}$} & $\mathrm{C}_{\mathrm{e}}(\mathrm{mg} / \mathrm{L})$ & $\mathrm{q}_{\mathrm{e}}(\mathrm{mg} / \mathrm{g})$ & $\log C_{e}$ & $\log \mathrm{q}_{\mathrm{e}}$ & $\mathrm{R} \%$ \\
\hline 4.87 & & 0.177 & 0.962 & -0.752 & -0.077 & 96.3 \\
\hline 9.52 &.$\overline{0} .0$ & 0.331 & 1.929 & -0.480 & 0.285 & 96.5 \\
\hline 13.95 & $\stackrel{0}{\tilde{0}} \overline{0}$ & 0.376 & 2.916 & -0.425 & 0.465 & 97.3 \\
\hline 18.18 & $=0$ & 0.551 & 3.878 & -0.259 & 0.589 & 96.9 \\
\hline 22.22 & II & 0.779 & 4.824 & -0.108 & 0.683 & 96.4 \\
\hline 11.9 & ฮี ฮี & 0.468 & 2.400 & -0.329 & 0.380 & 96 \\
\hline 22.7 & $\overline{0}$ & 0.988 & 4.776 & -0.0052 & 0.679 & 95.6 \\
\hline 41.6 & $\frac{2}{2}$ & 2.428 & 9.401 & 0.385 & 0.973 & 94.1 \\
\hline 57.6 & ల & 3.359 & 14.102 & 0.526 & 1.149 & 94.1 \\
\hline
\end{tabular}
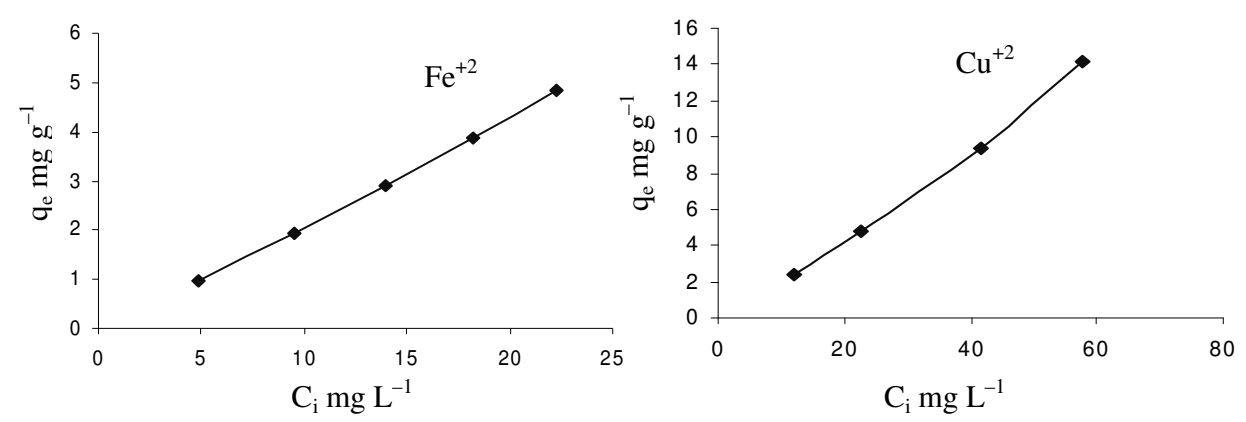

Figure 5. Effect of initial concentration of metal ions on adsorption

\section{Adsorption isotherm}

The experimental data were analyzed according to the linear form of the Freundlich isotherm, where, the langmuir isotherm did not give a linear plot. The Freundlich equation have employed for the adsorption of metal ions on the adsorbent. The Freundlich isotherm ${ }^{24}$ have represented as:

$$
\log q_{e}=\log K_{f}+1 / n \log C_{e}
$$


Where $\mathrm{q}_{\mathrm{e}}$ is the amount of metal ion adsorbed per gram of adsorbent $(\mathrm{mg} / \mathrm{g}) . \mathrm{C}_{\mathrm{e}}$ is the equilibrium concentration of metal ion in solution $(\mathrm{mg} / \mathrm{L}), \mathrm{K}_{\mathrm{f}}$ and $\mathrm{n}$ are constants incorporating all factors affecting the adsorption capacity and intensity of adsorption respectively. Linear plot of $\log \mathrm{q}_{\mathrm{e}}$ versus $\log \mathrm{C}_{\mathrm{e}}$ shows that the adsorption of ferrous and copper ions follows the Freundlich isotherm Figure 6. The linearity of Freundlich plot suggested the formation of homogenous monolayer of $\mathrm{Cu}$ (II) and $\mathrm{Fe}$ (II) on the outer surface of the sorbent ${ }^{12}$, the adsorption coefficient $\mathrm{K}_{\mathrm{f}}$ of ferrous ion on pine fruit powder was found to be $7.1 \mathrm{~L} / \mathrm{g}$ and that for copper ion was $4.67 \mathrm{~L} / \mathrm{g}$.

The high $\mathrm{K}_{\mathrm{f}}$ values indicate that the saturation time for adsorption of metal ion is attained quickly due to high affinity of pine fruit towards adsorbate, while low $\mathrm{K}_{\mathrm{f}}$ values indicate low adsorption rate of metal ion ${ }^{25,26}$. The values of $1 / \mathrm{n}$ were 1.11 and $0.87 \mathrm{mg} / \mathrm{g}$ for $\mathrm{Fe}$ and $\mathrm{Cu}$ ions respectively. The high value of $1 / \mathrm{n}$ signifies that the forces which are exerted on the surface of pine fruit powder during metal ion adsorption are strong. From the values of $K_{f}$ and $1 / n$ it is evident that pine fruit is more efficient for removal of $\mathrm{Fe}$ than $\mathrm{Cu}$ ions. The maximum adsorption capacity was $4.824 \mathrm{mg} / \mathrm{g}$ at $22.22 \mathrm{mg} / \mathrm{L}$ of ferrous ion in solution and that for copper was $14.1 \mathrm{mg} / \mathrm{g}$ at $57.6 \mathrm{mg} / \mathrm{L}$, at higher concentrations this maximum can be higher.
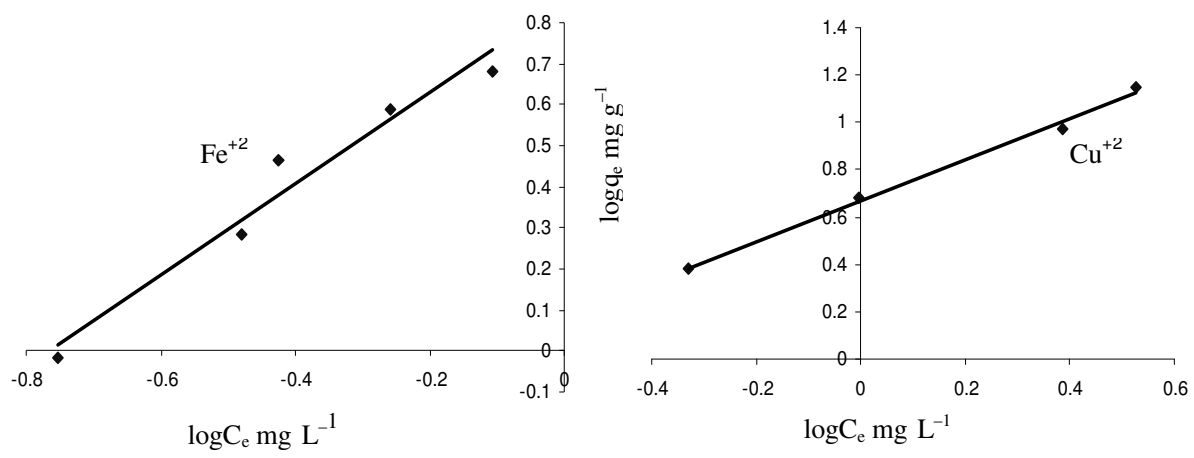

Figure 6. Freundlich isotherm for adsorption of copper and ferrous ions onto pine fruit powder.

\section{Conclusions}

From the experimental data of adsorption of ferrous and copper ions on pine fruit powder surface, the following points can be concluded.

1. Pine fruit powder, an agricultural waste, could be used as potential adsorbent for the removal of ferrous and copper ions from polluted water.

2. From the experimental data it is clear that the adsorption process for both metals is the same owing to the fact that the adsorption of $\mathrm{Fe}(\mathrm{II})$ and $\mathrm{Cu}$ (II) ions are well described by Freundlich isotherm.

3. The adsorption of metal ions on pine fruit powder was dependent on the equilibrium $\mathrm{pH}$ values of the solution and time.

4. The percent removal of ferrous and copper ions by the new adsorbent is fairly high; it ranges between 96.5 to 97.3 , and 94.1 to 97.2 respectively, among the whole range of initial concentration used in this study.

5 Kinetic of metal ions adsorption obeyed the pseudo-second-order models, which suggest chemisorption as the rate-determining step in adsorption process.

6. The amount of metal ions adsorbed increased with increase initial metal ion concentration. 


\section{References}

1. Sigel, H (Ed), Metal ions in biological System, Dekker, New York, 1988, p.24.

2. Scheinberg I H, Morell A G, Eichhorn G L (Ed), Ceruloplasmin in: Inorganic Biochemistry, Vol. 1, Elsevier, New York, 1973, pp.306-343.

3. Uzun I and Guzel F, Turk J Chem. 2000, 24, 291-297.

4. Vasu, A E, E J Chem. 2008, 5(1), 1-9.

5. Sudha R, Kalpana K, Rajachandrasek, T and Arivoli S, E J Chem., 2007, 4(2), 238-254.

6. Ho Y S, and Mckay G, Wat Res., 2000, 34, 735-742.

7. $\quad$ Qiming Y, JoseT M, Pinghe Y and Pairat K, Wat Res., 1999, 33,1534-1537.

8. Nassar M M, Ewida K T, Ebrahiem E E, Magdy Y H and Magdy Y H, J Environ Sci Health A, 2004, A39, 421-434.

9. Nassar M M, Hamoda M F and Radwan G H, Adsorption Sci and Tech., 1995, 13, 1-9.

10. Nassar M M and Magdi Y H, Chem Eng J., 1997, 66, 223- 227.

11. Hanafiah M A K, Ibrahim S C and Yahya M Z A , J Appl Sci Res., 2006, 2(12), 1169-1174.

12. Goyal P, Sharma P, Srivastava S and Srivastava M, Int J Environ Sci Tech., 2008, 5(1), 27-34.

13. Abdel-Ghani N T and Elchaghaby G A, Int J Environ Sci Tech., 2007, 4(4), 451-456.

14. Jia-You Shu, Mo Zhu, Yi shu, Qi-Jun Liu and Tong Li, Chinese J Polymer Sci., 2006, 24(4), 395-401.

15. Samal S, Acharya S, Dey R K and Ray A R, Talanta, 2001, 57, 1075-1083.

16. Coskun R and Soykan C, J Polymer Res, 2006, 13, 1-8.

17. Yigitoglu M and Arslan M, e-Polymers, 2007, 055.

18. Masram D T, Kariya K P and Bhave N, e-Polymers, 2007, 075.

19. Qaiser S, Saleemi A R and Ahmed M M, Electronic Journal of Biotechnology, 2007, 10, 3.

20. Sivaraj R, Namasivayam C and Kadirvelu, Waste Management, 2001, 21, 105.

21. Ho H S, Adsorption of Heavy Metals from Waste Streams by Peat, Ph. D. Thesis. The University of Birmingham, Birmingham UK. 1995.

22. Mckay G and Ho YS, Proc Biochem., 1999, 29, 1737.

23. Ncibi M C, Mahjoub B and Scffen M, J Hazard Mater., 2007, 139, 280.

24. Freundlich H, Phys Chemie, 1906, 57, 384.

25. Luo X Y, Su Z X, Zhang GY and Chang X J, Analyst 1992, 117, 145.

26. Schmuhl R, Krieg H M and Keizerk K, Water SA, 2001, 27, 1-7. 


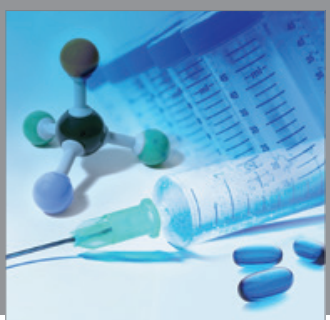

International Journal of

Medicinal Chemistry

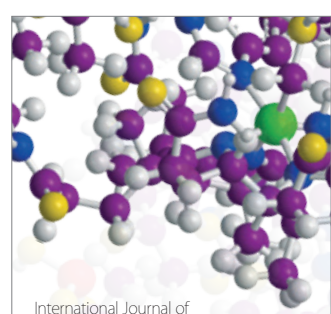

Carbohydrate Chemistry

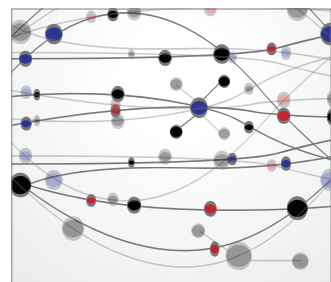

The Scientific World Journal
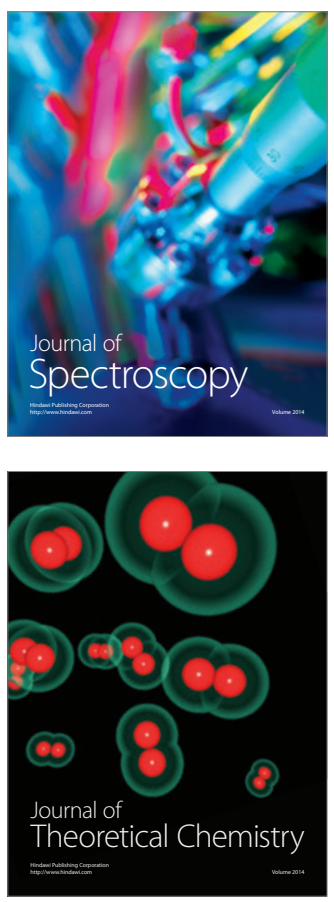
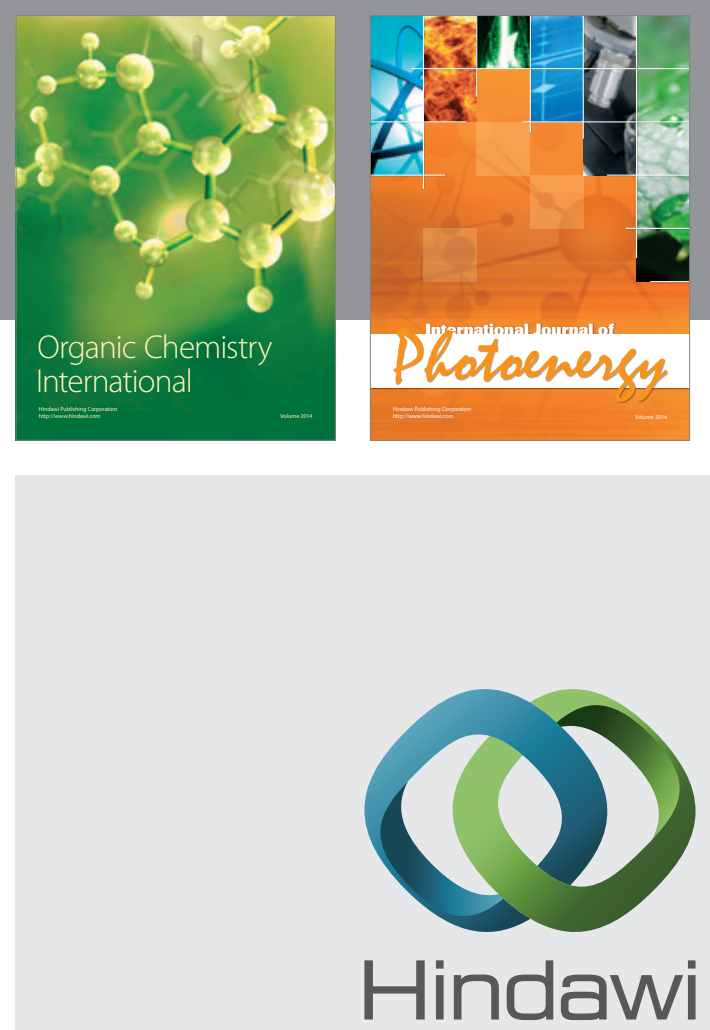

Submit your manuscripts at

http://www.hindawi.com
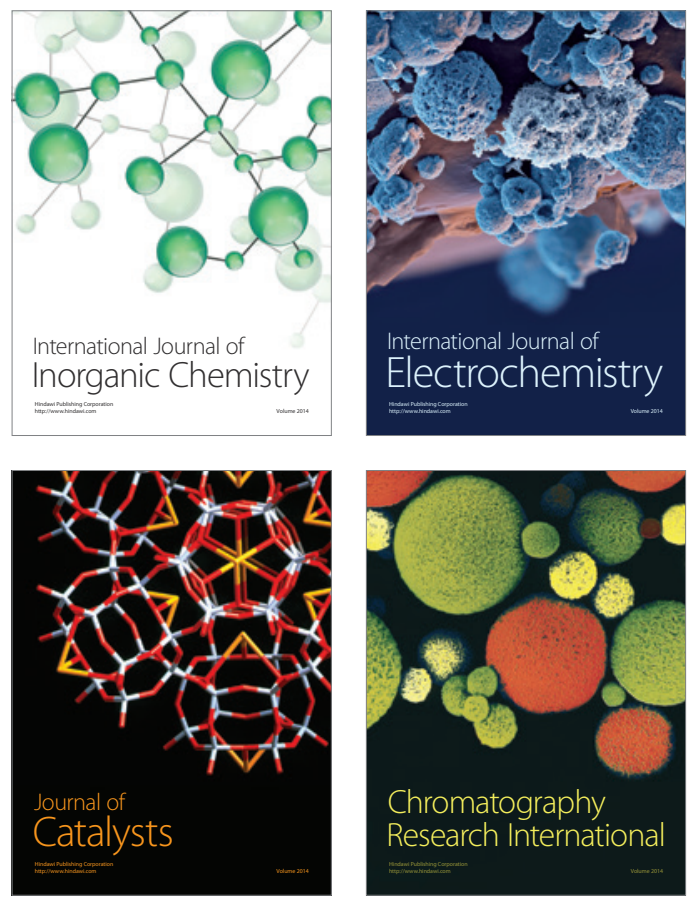
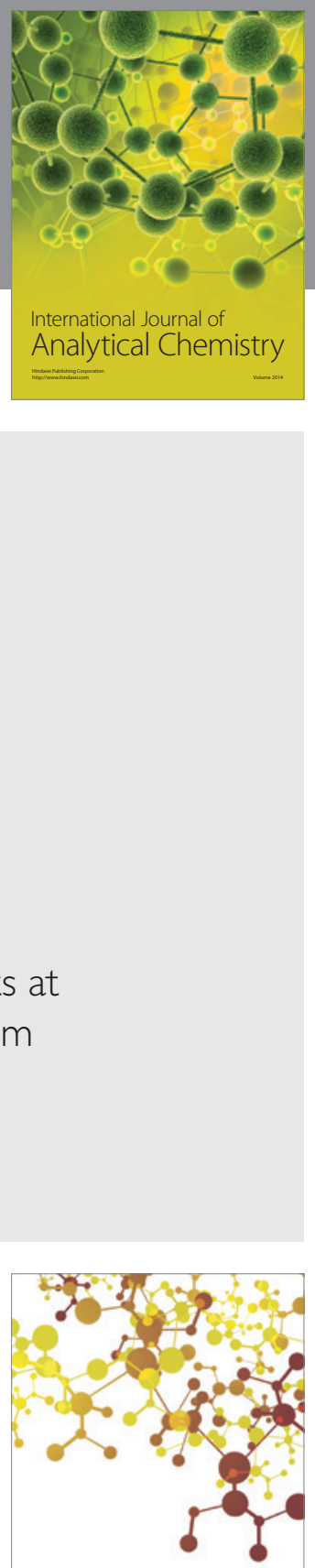

Journal of

Applied Chemistry
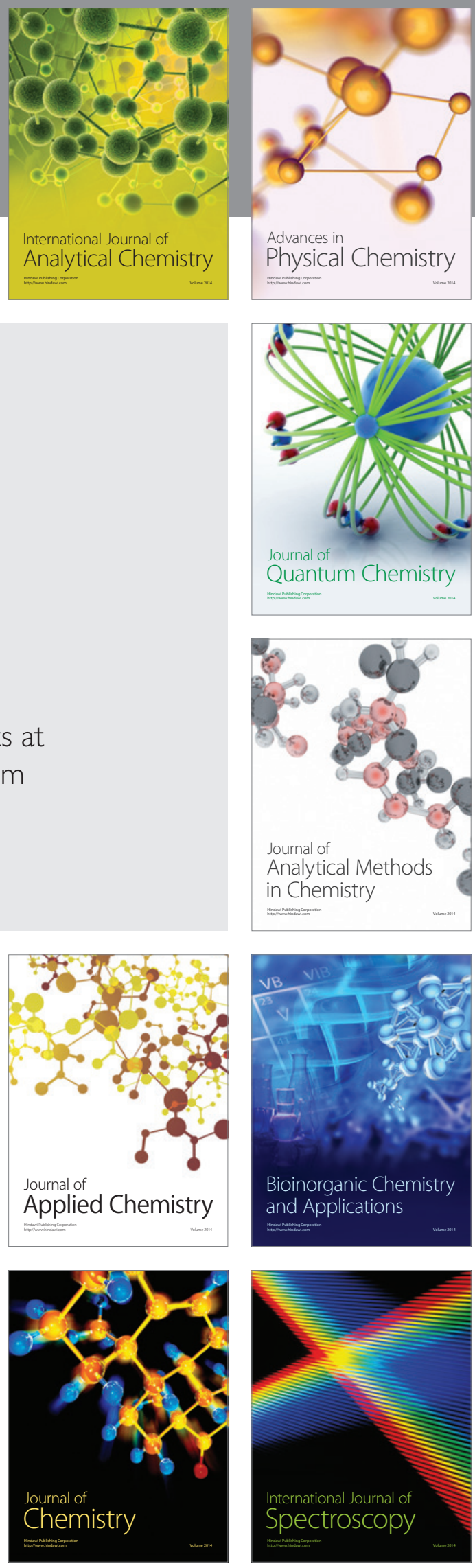